\title{
A New Pentacyclic Triterpene Isolated from Myroxylon balsamum (syn.Myroxylon peruiferum)
}

\author{
Leda Mathias ${ }^{\mathrm{a}}$, Ivo J. C. Vieira ${ }^{\mathrm{a}}$, Raimundo Braz-Filho ${ }^{\mathrm{a}^{*}}$ and Edson Rodrigues Filho ${ }^{\mathrm{b}}$ \\ ${ }^{a}$ Setor de Química de Produtos Naturais, LCQUI, CCT, Universidade Estadual do \\ Norte Fluminense, 28015-620, Campos - RJ, Brazil \\ ${ }^{b}$ Departamento de Química, Universidade Federal de São Carlos, São Carlos - SP, Brazil
}

\begin{abstract}
Um novo triterpeno pentacíclico, o $11 \alpha$-metoxi- $\beta$-amirina (1) foi isolado de Myroxylon balsamum (L.) Harms (sin.Myroxylon peruiferum L.f.). A estrutura desta substância foi elucidada pela análise de seus dados de IV, EM, RMN ${ }^{1} \mathrm{H}$ e ${ }^{13} \mathrm{C}$. RMN bidimensional foi também utilizada para definir a estrutura e atribuir os deslocamentos químicos dos átomos de hidrogênio e carbono do novo triterpeno.
\end{abstract}

The new pentacyclic triterpene, $11 \alpha$-methoxy- $\beta$-amyrin (1), was isolated from Myroxylon balsamum (L.) Harms (syn. Myroxylon peruiferum L.f.). Its structure was established on the basis of IR, MS, ${ }^{1} \mathrm{H}$ NMR, ${ }^{13} \mathrm{C}$ NMR. 2D NMR experiments were also used to establish the structure and the hydrogen and carbon chemical shift assignments of the new triterpene.

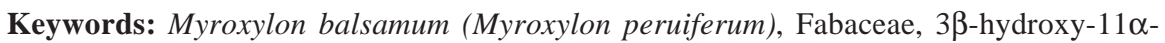
methoxyolean-12-ene

\section{Introduction}

Myroxylon balsamum (L.) Harms (syn. Myroxylon peruiferum L.f.), family Fabaceae, is a large size tree, with white flowers, winged and aromatic fruits. Its dispersion is wide, being spread from the South of Mexico until the North of Argentina. In Brazil, its distribution includes a vast range of the forest region of the country, being very common in the States of Bahia, Paraná and Mato Grosso. It is known as "cabriuna" and "cabriúna - vermelha"1.

The red-brown wood shows fine stripes, is a little rough and has a peculiar scent due to essential oil. It is a heavy wood and is resistant to deterioration, being widely used in carpentry. The hurtled log supplies a well-known exudate known as balsam of Peru or Tolu or a red oil which is quite rich in vanilla. The oil was used formerly in popular medicine as expectorant for breathing affections and as a sedative in cases of cystitis. Now its use is limited to the perfumery industry and as sedative pills for coughs $1-2$. Chemically, the balsam is a mixture of free acids, especially benzoic and cinnamic, and benzyl benzoate. This plant also furnishes a resinous fraction containing monoterpenoids, sesquiterpenoids, alcohols and phenylpropanoids derivatives $^{2}$. From trunk wood were isolated isoflavones, pterocarpan, coumestans, flavanone, isoflavanones and arylbenzofuran 3,4 .
In this paper we report the isolation and structural determination of a new pentacyclic triterpene 1 from the leaves of a specimen of Myroxylon balsamum (Fabaceae) collected in Espirito Santo State, Brazil. The structure was established by spectral analysis of $\mathbf{1}$ and its acetyl derivative $\mathbf{1 a}$, mainly through ${ }^{1} \mathrm{H}$ and ${ }^{13} \mathrm{C}$ NMR spectra, including homonuclear ${ }^{1} \mathrm{H}-1{ }^{1} \mathrm{HCOSY}$ and heteronuclear ${ }^{1} \mathrm{H}$ detected (inverse method) ${ }^{1} \mathrm{H}-{ }^{13} \mathrm{C} \mathrm{HMQC}{ }^{1} J_{\mathrm{CH}}$ and ${ }^{1} \mathrm{H}-13 \mathrm{C} \mathrm{HMBC}{ }^{n} J_{\mathrm{CH}}(\mathrm{n}=2$ and 3$)$ 2D shift-correlated spectra 5 .

\section{Results and Discussion}

The pentacyclic triterpene $\mathbf{1}$ was obtained as colorless crystals whose molecular formula $\mathrm{C}_{31} \mathrm{H}_{52} \mathrm{O}_{2}$ (6 unsaturations) was deduced by comparative analysis of ${ }^{13} \mathrm{C}$ NMR (31 singlet signals) and DEPT- ${ }^{13}$ C NMR data ${ }^{6}$ (Table 1 ) $\left[\theta=90^{\circ}: 6 \mathrm{CH}\right.$, including one $\mathrm{sp}^{2}\left(\delta_{\mathrm{C}} 121.51, \mathrm{CH}-12\right)$ and two $\mathrm{sp}^{3}$ oxygenated $\left(\delta_{\mathrm{C}} 78.61, \mathrm{CH}-3\right.$, and $\left.75.85, \mathrm{CH}-11\right) ; \theta=$ $135^{\circ}: 9 \mathrm{CH}_{2}$ and $9 \mathrm{CH}_{3}$ including one methoxy group $\left(\delta_{\mathrm{C}}\right.$ 53.67, MeO-11)] and LREIMS [m/z 424, 100\% (M-MeOH]. The DEPT results $\left[6 \mathrm{CH}, 9 \mathrm{CH}_{2}\right.$ and $9 \mathrm{CH}_{3}=\mathrm{C}_{24} \mathrm{H}_{51}$ ] indicated that one exchangeable hydrogen (hydroxy group) was present, in accordance with the absorption at $v_{\max }$ $3380 \mathrm{~cm}^{-1}$ observed in the IR spectrum and a monoacetyl $\left[\delta_{\mathrm{H}} 2.03(s)\right]$ derivative (1a) obtained by treatment with $\mathrm{Ac}_{2} \mathrm{O}$ in the presence of pyridine (see experimental). The 
${ }^{13} \mathrm{C}$ NMR spectra of 1 revealed signals at $\delta_{\mathrm{C}} 121.51(\mathrm{CH}-$ 12) and 149.67 (C-13), indicating the presence of a double bond. Because the unsaturation number is 6,1 must therefore be a pentacyclic triterpene.

The location of the methoxy group at $\mathrm{CH}-11\left(\delta_{\mathrm{C}} 75.85\right.$ and $\left.\delta_{\mathrm{H}} 3.84\right)$ and not at $\mathrm{CH}-3\left(\delta_{\mathrm{C}} 78.61\right.$ and $\left.\delta_{\mathrm{H}} 3.23\right)$ was defined by heteronuclear long-range couplings between $\mathrm{CH}-11\left(\delta_{\mathrm{C}} 75.85\right)$ and the methoxyl hydrogens $\left(\delta_{\mathrm{H}} 3.23\right.$, $\left.{ }^{3} J_{\mathrm{CH}}\right), \mathrm{CH}-12\left(\delta_{\mathrm{C}} 121.51\right)$ and $\mathrm{H}-11\left(\delta_{\mathrm{H}} 3.84,{ }^{2} J_{\mathrm{CH}}\right)$ and $\mathrm{C}-13$ $\left(\delta_{\mathrm{C}} 149.67\right)$ and $\mathrm{H}-11\left(\delta_{\mathrm{H}} 3.84,{ }^{3} J_{\mathrm{CH}}\right)$ observed in the HMBC spectrum (Table 1). Other heteronuclear long-range couplings are summarized in Table 1.

The ${ }^{1} \mathrm{H}$ NMR spectrum of $\mathbf{1}$ (Table 1) showed nine singlet signals corresponding to one methoxy $\left[\delta_{\mathrm{H}} 3.23(\mathrm{MeO}-\right.$ 11)] and eight tertiary methyl groups $\left[\delta_{\mathrm{H}} 1.21(3 \mathrm{H}-27), 1.04\right.$ $(3 \mathrm{H}-25), 1.00(3 \mathrm{H}-23), 0.99(3 \mathrm{H}-26), 0.91(3 \mathrm{H}-29), 0.89(3 \mathrm{H}-$ 30), $0.83(3 \mathrm{H}-28)$ and $0.80(3 \mathrm{H}-24)]$.

The position of $\mathrm{H}-11$ in $\mathbf{1}\left[\delta_{\mathrm{H}} 3.84(d d, J=3.5\right.$ and $8.9 \mathrm{~Hz})$ ] was defined as axial (H-11 $\beta)$ on the basis of its coupling constant with $\mathrm{H}-9\left(\delta_{\mathrm{H}} 1.69, d, J=8.9 \mathrm{~Hz}\right)$. The equatorial orientation of the hydroxyl group at $\mathrm{CH}-3$ (H-3 axial) was deduced by comparative analysis of the chemical shifts corresponding to $\mathrm{CH}_{2}-1\left(\delta_{\mathrm{C}} 39.26\right), \mathrm{CH}_{2}-2\left(\delta_{\mathrm{C}} 27.30\right), \mathrm{CH}-3$ $\left(\delta_{\mathrm{C}} 78.61\right), \mathrm{CH}-5\left(\delta_{\mathrm{C}} 55.02\right), \mathrm{CH}_{3}-24\left(\delta_{\mathrm{C}} 15.44\right)$ of 1 and the model triterpenoids 2 and 3 supporting a $\mathrm{HO}-3 \beta(\mathrm{H}-3 \alpha)$ and $\mathrm{HO}-3 \alpha(\mathrm{H}-3 \beta)\left[2(\mathrm{HO}-3 \beta) / 3(\mathrm{HO}-3 \alpha): \delta_{\mathrm{C}} 39.5 / 33.5\left(\mathrm{CH}_{2}-1\right)\right.$, 27.4/25.4 ( $\left.\mathrm{CH}_{2}-2\right), 78.7 / 76.0(\mathrm{CH}-3), 39.0 / 37.0(\mathrm{C}-4), 55.1 / 48.8$ $(\mathrm{CH}-5)$ and $\left.15.5 / 22.4\left(\mathrm{CH}_{3}-24\right)\right]^{7}$, since superimposition of the signals was observed for $\mathrm{H}-3\left(\delta_{\mathrm{H}} 3.23\right)$ and the methoxyl group $\left(\delta_{\mathrm{H}} 3.23\right)$ in the ${ }^{1} \mathrm{H}$ NMR. The shielding revealed by the chemical shifts corresponding to carbon signals of $\mathrm{CH}_{2}-$ $1, \mathrm{CH}-5$ and $\mathrm{CH}_{3}-24$ of 3 can be justified by $\gamma$-effects attributed to the hydroxyl group at an axial position (H-3 $\beta$ equatorial). This deduction was confirmed by ${ }^{1} \mathrm{H}$ NMR and ${ }^{1} \mathrm{H}-1 \mathrm{H}$ COSY spectra (200 MHz) of the monoacetyl derivative 1a, which revealed the signal corresponding to $\mathrm{H}-3$ as a double doublet $[J=8.2$ (axial-axial interaction) and $5.0 \mathrm{~Hz}]$ at $\delta_{\mathrm{H}} 4.49$ $\left[\Delta \delta_{\mathrm{H}}=4.49(\mathbf{1 a})-3.23(\mathbf{1})=1.26 \mathrm{ppm}\right]$.

${ }^{1} \mathrm{H}$ and ${ }^{13} \mathrm{C} \mathrm{NMR}$ assignments (Table 1 ) of the pentacyclic triterpene 1 were determined on the basis of HMQC

Table 1. ${ }^{1} \mathrm{H}$ and ${ }^{13} \mathrm{C}$ NMR spectral data for $1\left(\mathrm{CDCl}_{3}\right)$.*

\begin{tabular}{|c|c|c|c|c|}
\hline & \multicolumn{2}{|c|}{ HMQC } & \multicolumn{2}{|c|}{ HMBC } \\
\hline $\mathbf{C}$ & $\delta_{\mathrm{C}}$ & $\delta_{\mathrm{H}}$ & ${ }^{2} J_{\mathrm{CH}}$ & ${ }^{3} J_{\mathrm{CH}}$ \\
\hline 4 & 39.00 & - & $3 \mathrm{H}-23 ; 3 \mathrm{H}-24$ & $\mathrm{H}-2$ \\
\hline 8 & 43.05 & - & $\mathrm{H}-9 ; 3 \mathrm{H}-26$ & $3 \mathrm{H}-27$ \\
\hline 10 & 38.12 & - & $\mathrm{H}-1 \mathrm{a} ; \mathrm{H}-9 ; 3 \mathrm{H}-25$ & H-11 \\
\hline 13 & 149.67 & - & & $\mathrm{H}-11 ; 3 \mathrm{H}-27$ \\
\hline 14 & 41.70 & - & $3 \mathrm{H}-27$ & $\mathrm{H}-12 ; 3 \mathrm{H}-26$ \\
\hline 17 & 32.30 & - & $3 \mathrm{H}-28$ & $\mathrm{H}-16$ \\
\hline 20 & 31.07 & - & Н-19; 3Н-29; 3Н-30 & \\
\hline \multicolumn{5}{|l|}{$\mathbf{C H}$} \\
\hline 3 & 78.61 & 3.23 & $\mathrm{H}-2$ & $2 \mathrm{H}-1 ; 3 \mathrm{H}-23 ; 3 \mathrm{H}-24$ \\
\hline 5 & 55.02 & 0.78 & & $\mathrm{H}-1 ; 3 \mathrm{H}-23 ; 3 \mathrm{H}-24 ; 3 \mathrm{H}-25$ \\
\hline 9 & 51.56 & $1.69(d, J=8.9)$ & $\mathrm{H}-11$ & H-12; 3H-25; 3H-26 \\
\hline 11 & 75.85 & $3.84(d d, J=3.5,8.9)$ & $\mathrm{H}-9$ & MeO-11 \\
\hline 12 & 121.51 & $5.34(d, J=3.5)$ & $\mathrm{H}-11$ & H-18 \\
\hline 18 & 46.76 & 1.99 & & $\mathrm{H}-12 ; 3 \mathrm{H}-28$ \\
\hline \multicolumn{5}{|l|}{$\mathrm{CH}_{2}$} \\
\hline 1 & 39.26 & $1.91(t d, J=13.9,3.3) ; 1.23$ & & $3 \mathrm{H}-25$ \\
\hline 2 & 27.30 & 1.63 & & \\
\hline 6 & 18.24 & $1.48 ; 0.96$ & & \\
\hline 7 & 33.08 & $1.49 ; 1.31$ & & $3 \mathrm{H}-26$ \\
\hline 15 & 26.13 & $1.25 ; 1.00$ & & $3 \mathrm{H}-27$ \\
\hline 16 & 26.60 & $2.01 ; 1.69$ & & $3 \mathrm{H}-28$ \\
\hline 19 & 46.36 & $1.65 ; 1.08$ & & $3 \mathrm{H}-29 ; 3 \mathrm{H}-30$ \\
\hline 21 & 34.51 & $1.15 ; 1.00$ & & $3 \mathrm{H}-29 ; 3 \mathrm{H}-30$ \\
\hline 22 & 36.84 & $1.46 ; 1.23$ & & $3 \mathrm{H}-28$ \\
\hline \multicolumn{5}{|l|}{$\mathrm{CH}_{3}$} \\
\hline 23 & 28.03 & $1.00(s)$ & & $3 \mathrm{H}-24$ \\
\hline 24 & 15.44 & $0.80(s)$ & & $3 \mathrm{H}-23 ; \mathrm{H}-5$ \\
\hline 25 & 18.04 & $1.04(s)$ & & $\mathrm{H}-9$ \\
\hline 26 & 16.76 & $0.99(s)$ & & \\
\hline 27 & 25.07 & $1.21(\mathrm{~s})$ & & H- 18 \\
\hline 28 & 28.35 & $0.83(s)$ & & \\
\hline 29 & 33.11 & $0.91(s)$ & & \\
\hline 30 & 23.52 & $0.89(s)$ & & Н-19; 3Н-29 \\
\hline MeO-11 & 53.67 & $3.23(s)$ & & H-11 \\
\hline
\end{tabular}

*Chemical shifts $\left(\delta_{\mathrm{H}}\right.$ and $\left.\delta_{\mathrm{C}}\right)$ and ${ }^{1} \mathrm{H}$ coupling constants $\left(J\right.$ in $\mathrm{Hz}$, in parenthesis) obtained from the one dimensional ${ }^{1} \mathrm{H}$ and ${ }^{13} \mathrm{C}$ NMR spectra Multiplicity of signals of carbon atoms deduced by comparative analysis of HBBD- and DEPT- ${ }^{13} \mathrm{C}$ NMR spectra. Homonuclear ${ }^{1} \mathrm{H}-{ }^{1} \mathrm{H}$ COSY and heteronuclear ${ }^{1} \mathrm{H}-{ }^{13} \mathrm{C} \mathrm{HMQC}{ }^{1} J_{\mathrm{CH}}$ and ${ }^{1} \mathrm{H}_{-}{ }^{13} \mathrm{C}$ HMBC ${ }^{\mathrm{n}} J_{\mathrm{CH}}(\mathrm{n}=2$ and 3) $2 \mathrm{D}$ NMR spectra were also used for these assignments. 
and HMBC data and comparison to the known triterpene 2 $[11 \alpha$-hydroxy- $\beta$-amyrin, isolated from callus tissues of Stauntonia hexaphylla (Lardizabalaceae) $]^{8}$. The ${ }^{13} \mathrm{C} \mathrm{NMR}$ spectra of $\mathbf{1}$ (Table 1), the 11-O-methyl ether of $\mathbf{2}$, showed signals that matched closely with those of the triterpene 2 (recorded in $\left.\mathrm{CDCl}_{3}\right)^{8}$, revealing significant differences only in the chemical shifts of the methine $\mathrm{CH}-11\left[\delta_{\mathrm{C}} 75.85(\mathbf{1})\right.$ and $81.70(2)]$ and the quaternary $\mathrm{C}-13\left[\delta_{\mathrm{C}} 149.67(\mathbf{1})\right.$ and 153.20 (2)] carbon atoms. These different chemical shifts may be justified by the presence of a hydrogen bond involving the hydroxy group at $\mathrm{CH}-11$ of 2 and the solvent pyridine- $d_{5}$, and not in $\mathrm{CDCl}_{3}$ as reported in the literature 8 . The ${ }^{13} \mathrm{C}$ and ${ }^{1} \mathrm{H}$ chemical shifts of the methine $\mathrm{CH}-11$ $\left[\delta_{\mathrm{C}} 76.6\right.$ and $\delta_{\mathrm{H}} 3.87(d d, J=3.5$ and $\left.8.6 \mathrm{~Hz})\right]$ of camaldulensis acid (3ß,30-dihydroxy-11 $\alpha$-methoxyurs-12-en-28-oic acid, 4, recorded in $\mathrm{CD}_{3} \mathrm{OD}$ ), isolated from leaves of Eucalyptus camaldulensis var. obtusa (Myrtaceae) ${ }^{9}$, and $3\left(\delta_{C} 68.4\right)^{7}$ were also used in this analysis.

Thus, the structure of the new triterpenoid isolated from Myroxylon balsamum was established as 3 $\beta$-hydroxy- $11 \alpha$ methoxyolean-12-ene (1). The prominent peaks at $m / z 255$ (60\%) and 271 (16\%) observed in the mass spectrum, which could result from cleavage involving the rings $\mathrm{B}$ and $\mathrm{D}$, respectively, in accordance with the formation of a diene after $\mathrm{MeOH}$ elimination ${ }^{10}$, were also used in this structural elucidation. To the best of our knowledge, this triterpene 1 is hitherto unreported.
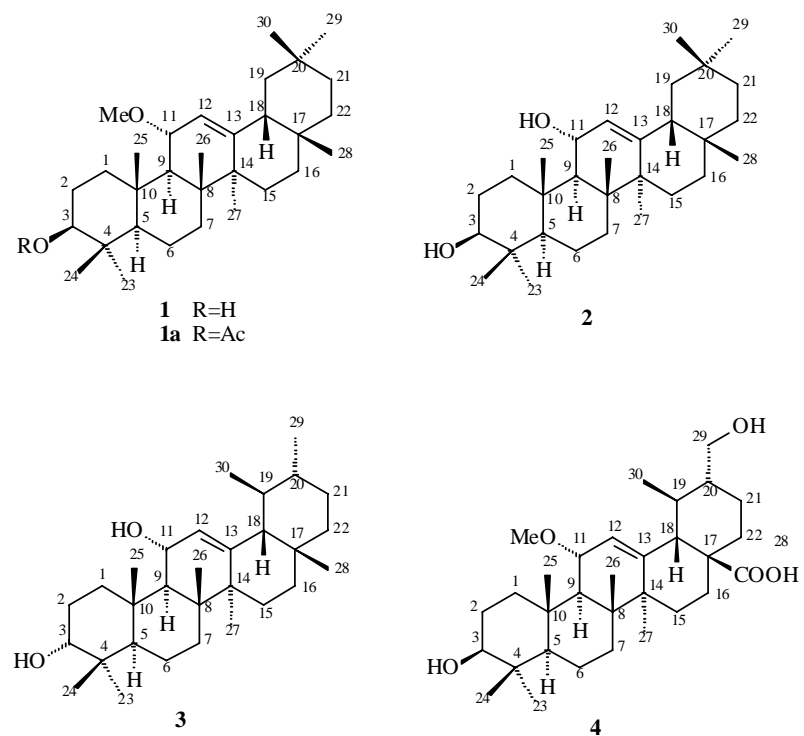

Other 11-hydroxy or 11-methoxy pentacyclic triterpenes described in the literature are 28-oic acids: $2 \alpha, 3 \beta, 23$-trihydroxy-11 $\alpha$-methoxyurs-12-en-28-oic acid [isolated from resin of Shorea robusta (Dipterocarpaceae) ${ }^{11}, 11 \alpha$-hydroxybetulinic acid [isolated from leaves of Licania pyrifolia
(Crysobalanaceae) $]^{12}$ and $11 \alpha$-hydroxytormentic acid [2 $\alpha, 3 \beta, 11 \alpha, 19 \alpha$-tetrahydroxyurs-12-en-28-oic acid, isolated from aerial parts of Rosa laevigata (Rosaceae) $]^{13}$.

\section{Experimental}

\section{General Experiments Procedures}

EIMS were recorded on a VG Platform II mass spectrometer. ${ }^{1} \mathrm{H}(400 \mathrm{MHz}),{ }^{13} \mathrm{C}(100 \mathrm{MHz}),{ }^{1} \mathrm{H}-13 \mathrm{C} \mathrm{HMQC}$ ${ }^{1} J_{\mathrm{CH}}$ and ${ }^{1} \mathrm{H}-{ }^{13} \mathrm{C} \mathrm{HMBC}{ }^{n} J_{\mathrm{CH}}(\mathrm{n}=2$ and 3 spectra were recorded using on a BrukerARX-400 spectrometer, in $\mathrm{CDCl}_{3}$ as solvent; residual $\mathrm{CHCl}_{3}\left(\delta_{\mathrm{H}} 7.24\right)$ and the central peak of the triplet of $\mathrm{CDCl}_{3}\left(\delta_{\mathrm{C}} 77.00\right)$ were used as internal references. The multiplicities of the carbon signals were deduced by comparative analysis of the HBBD- and DEPT-13CNMR spectra. Heteronuclear ${ }^{1} \mathrm{H}$ and ${ }^{13} \mathrm{C}$ connectivities were deduced by ${ }^{1} \mathrm{H}-13 \mathrm{C} \mathrm{HMQC}{ }^{1} J_{\mathrm{CH}}$ [spin-spin coupling of carbon and hydrogen via one bond $\left.\left({ }^{1} J_{\mathrm{CH}} 145.0 \mathrm{~Hz}\right)\right]$ and ${ }^{1} \mathrm{H}-$ ${ }^{13} \mathrm{C} \mathrm{HMBC}{ }^{n} J_{\mathrm{CH}}[\mathrm{n}=2$ and 3 , spin-spin interaction of carbon and hydrogen via two $\left(2 J_{\mathrm{CH}}\right)$ and three $\left({ }^{3} J_{\mathrm{CH}}\right)$ bonds, optimized for ${ }^{n} J_{C H}$ of $9 \mathrm{~Hz}$ ]. IR spectra with $\mathrm{KBr}$ plates were obtained on a FTIR Perkin-Elmer 1600/1605 spectrometer.

\section{Plant material}

The leaves of Myroxylon balsamum were collected at Reserva Florestal de Linhares, Companhia Vale do Rio Doce (CVRD), Espirito Santo State, Brazil, during September 1996. A voucher specimen has been deposited in the CVRD Herbarium (voucher no CVRD-483).

\section{Extraction and Isolation}

The air dried and powdered leaves (328.0 g) of Myroxylon balsamum were successively extracted with hexane, EtOAc and $\mathrm{MeOH}$ at room temperature and the solvents removed under vacuum to yeld $36.1 \mathrm{~g}$ (rich in waxes and carotenoids), $17.4 \mathrm{~g}$ and $5.25 \mathrm{~g}$ of residues, respectively. The residue (17.4) obtained from the EtOAc solution was chromatographed on a of silica gel column eluting with hexane/ $\mathrm{CH}_{2} \mathrm{Cl}_{2}$ mixtures of increasing polarity; a total of 45 fractions ( $c a .100 \mathrm{~mL}$ each one) were collected and combined of the basis of TLC comparison. The fractions 18-22, eluted with hexane- $\mathrm{CH}_{2} \mathrm{Cl}_{2}(1: 1)$, furnished $\mathbf{1}(92.0 \mathrm{mg})$ after recristalization from $\mathrm{CHCl}_{3}$.

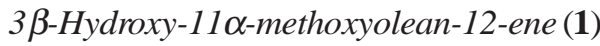

Colorless crystals, mp $172-173^{\circ} \mathrm{C},[\alpha]_{\mathrm{D}}+12.4^{\circ}(\mathrm{c} 0.73$, $\left.\mathrm{CH}_{2} \mathrm{Cl}_{2}\right)$; $\mathrm{IR}(\mathrm{KBr}) v_{\max } 3380,1461,1384,1044,915,731 \mathrm{~cm}^{-1}$; EIMS $m / z$ (rel. int.) 456 (M+• abs.), 425 (25, M-MeO·), 424 
(100, M-MeOH), 409 (51, M-MeOH-Me•), 271 (16), 255 (60), $253(6) ;{ }^{1} \mathrm{H}\left(400 \mathrm{MHz}, \mathrm{CDCl}_{3}\right)$ and ${ }^{13} \mathrm{C}\left(100 \mathrm{MHz}, \mathrm{CDCl}_{3}\right)$ NMR:Table 1.

$3 \beta$-Acetoxy-11 $\alpha$-methoxyolean-12-ene

(1a, acetyl derivative of $\mathbf{1})$

A sample of $\mathbf{1}(18.0 \mathrm{mg})$ was treated with $\mathrm{Ac}_{2} \mathrm{O}(2.0 \mathrm{~mL})$ and dry pyridine $(1.0 \mathrm{~mL})$ at room temperature overnight. After the usual work-up, the crude product was chromatographed on a silica gel column eluting with $\mathrm{CHCl}_{3}$ to furnish the acetyl derivative $1 \mathbf{a}(16.0 \mathrm{mg})$ as colorless crystals, mp $149-151^{\circ} \mathrm{C},[\alpha]_{\mathrm{D}}+5.7^{\circ}\left(\mathrm{c} 0.965, \mathrm{CH}_{2} \mathrm{Cl}_{2}\right)$; EIMS (rel. int.) 498 (M+• abs.), 466 (100, M-MeOH), 451 (8, M$\mathrm{MeOH}$ - Me·), 391 (14, M - MeOH - Me- AcOH), 255 (42), $253(10) ;{ }^{1} \mathrm{H} \mathrm{NMR}\left(200 \mathrm{MHz}, \mathrm{CDCl}_{3}\right) \delta_{\mathrm{H}} 5.30$ (br s, H-12), $4.49(d d, J=8.2$ and $5.0 \mathrm{~Hz}), 3.88(d d, J=8.8$ and $3.6 \mathrm{~Hz}), 3.18$ $(s, \mathrm{MeO}-11), 2.03$ ( $s$, AcO-3), 1.23 ( $s, 3 \mathrm{H}-23), 1.18(s, 3 \mathrm{H}-14)$, $1.04(s, 3 \mathrm{H}-25), 0.98(s, 3 \mathrm{H}-26), 0.86(s, 3 \mathrm{H}-27,3 \mathrm{H}-28,3 \mathrm{H}-29)$, $0.81(s, 3 \mathrm{H}-30)$.

\section{Acknowledgements}

The authors are grateful to the Programa de Apoio ao Desenvolvimento Científico e Tecnológico (PADCT)/ Financiadora de Estudos e Projetos (FINEP) and Fundação Estadual do Norte Fluminense (FENORTE) for grants, to CNPq for a research fellowship, and to Dr. Vitor Rumjanek for reading the manuscript.

\section{References}

1. Rizzini, C.T.; Mors, W. B. Botânica Econômica Brasileira (2nded); ÂmbitoCultural: Riode Janeiro, Brasil, 1995;p.156.

2. Bruneton, J. Pharmacognosy, Phytochemistry, Medicinal Plants; Lavoisier Publishing: Paris, France, 1995; p.224.

3. Oliveira, A. B. de; Madruga, M. I. L. M.; Gottlieb, O. R. Phytochemistry 1978, 17, 593.

4. Maranduba, A.; Oliveira, A. B. de; Oliveira, G. G. de; Reis, J.E. de P.; Gottlieb, O. R.Phytochemistry 1979, 18, 815.

5. Sanders, J. K. M.; Hunter, B. K. Modern NMR Spectroscopy: A Guide for Chemists (2nd ed.); Oxford University Press: Oxford, 1993.

6. Breitmaier, E.; Voelter, W. Carbon-13 NMR Spectroscopy: High Resolution Methods and Applications in Organic Chemistry and Biochemistry (3rd ed.); VCH: Weinheim, 1987.

7. Mahato, S. B.; Kundu, A. P. Phytochemistry 1994, 37, 1517.

8. Ikuta, A.; Morikawa, A. J. Nat. Prod. 1992, 55, 1230.

9. Begum, S.; Farhat; Siddiqui, B. S. J. Nat. Prod. 1997, 60, 20.

10. Barnes, R.A.; Pereira, A. L.; Scofield, C. V.; Braz-Filho, R.; Pinto, A. C. Chem. Pharm. Bull. 1984, 32, 3674.

11. Hota, R. K.; Bapuji, M. Phytochemistry 1993, 32, 466.

12. Bilia, A. R.; Morelli, I.; Mendez, J. J. Nat Prod. 1996, 59, 297.

13. Fang, J. M.;Wang, K. C.; Cheng, Y. S. Phytochemistry 1991, 30, 3383.

Received: February 18, 1999 